\title{
TOTAL FREE TOCOPHEROLS IN THE SERUM OF PATIENTS WITH THYROID DISEASE ${ }^{1}$
}

\author{
By SHOLEM POSTEL \\ (From the Department of Medicine of the Harvard Medical School and the Medical Services \\ of the Massachusetts General Hospital, Boston, Mass.)
}

(Submitted for publication June 8, 1956; accepted August 9, 1956)

The extent of muscle disease encountered at a given level of clinical hyperthyroidism varies from mild subjective weakness to severe disabling myopathy (1). Inconstancy and variable severity of muscle involvement point to some factor apart from the thyrotoxic state per $s e$ in its genesis. The possibility that exhaustion of tocopherol stores is the critical variable is raised by analogy between the dystrophic morphologic changes, increased oxygen consumption, hypercreatinuria, and depletion of muscle creatine which accompany thyroid hormone excess in animals and man (2-6), and similar alterations due to tocopherol deficiency in rodents (7-11). The mechanisms of these changes are not established, but there is evidence that in both hyperthyroidism (12-14) and tocopherol deficiency $(15,16)$ impairment of high energy phosphorylations results in uncontrolled release of energy derived from biological oxidations.

The possibility of tocopherol depletion in thyrotoxicosis is supported by evidence of accelerated turnover of other vitamins (17), cholesterol (18), and calcium (19) in hyperthyroidism. Increased tocopherol requirement in the hyperthyroid state is suggested by susceptibility of chicks given excess thyroid hormone to vitamin E deficiency (20). Of further interest are the reports of prevention of thyroxine induced creatinuria in rats (21) and children (22) by $\alpha$-tocopherol. These considerations stimulated the present survey of the concentration of tocopherols in sera of patients with thyroid disease.

\section{METHODS}

Subjects. Observations were made on 115 persons classified as follows:

a. Twenty-nine consecutive patients in whom the diagnosis of Graves' disease was made on clinical grounds and supported by measurement of basal metabolic rate, 24-hour thyroidal uptake of radioactive iodine and, in

1 Supported in part by a grant from the United States Public Health Service (A-849). most cases, determination of the serum concentration of protein bound iodine.

b. Five patients with active Graves' disease by the above-noted criteria who received specific antithyroid therapy within two weeks prior to the first tocopherol determination.

c. Eighteen consecutive patients who were clinically hypothyroid and in whom the above-mentioned tests of thyroid function supported the diagnosis. This group includes one patient receiving methimazole, two patients with spontaneous primary hypothyroidism, and fifteen who developed myxedema after $I^{12 x}$ treatment of hyperthyroidism or, in one case, heart disease.

d. Thirty random normal subjects, judged to have no significant medical or surgical illness by history, physical examination, and routine laboratory screening consisting of Hinton test, hemoglobin determination, chest roentgenogram, and urinalysis.

e. Thirty-three individuals in the euthyroid state but not otherwise normal. Nineteen had received treatment for hyperthyroidism in the past, one had hepatic cirrhosis, one Hodgkins' lymphoma, one a nodular goiter, and one was in the terminal phase of amyotrophic lateral sclerosis. Three members of this group had diabetes mellitus, and the remaining seven coronary artery or hypertensive vascular disease. In calculating the mean serum tocopherol concentration of the overall euthyroid group, i.e., normal controls plus euthyroid patients with various disorders, the ten patients with diabetes and vascular disease were excluded because they had obviously high levels.

Characterization of the major groupings as to age, sex, height, and weight is summarized in Table I. With the exception of eight thyrotoxic patients and two hypothyroid ones who were hospitalized, all subjects were ambulatory and on self-determined diets.

Tocopherol determinations. The concentration of total free tocopherols in serum was measured by the method of Quaife and Harris (23) as modified by Quaife and Biehler (24). It consists of hexane extraction of $5 \mathrm{ml}$. of alcohol precipitated serum, palladium catalyzed hydrogenation of the extract for one minute at 20 pounds pressure, and a timed determination of the reduction of ferric ion using the color of the iron $\alpha$ - $\alpha$-dipyridyl complex as indicator. This method, though not specific, yields results which agree to within 5 per cent with bioassays (23). In the present study, duplicate analyses were made on different days with a simultaneous standard curve accompanying each group of 10 unknowns. The 
TABLE I

Sex, age, height, and weight of subjects grouped according to thyroid status

\begin{tabular}{|c|c|c|c|c|c|c|}
\hline \multirow[b]{2}{*}{ Group } & \multirow[b]{2}{*}{ Number } & \multirow{2}{*}{$\begin{array}{c}\% \\
\text { Males }\end{array}$} & \multicolumn{2}{|c|}{ Age (years) } & \multirow{2}{*}{$\begin{array}{c}\text { Mean } \\
\text { height } \\
\mathrm{cm} .\end{array}$} & \multirow{2}{*}{$\begin{array}{c}\text { Mean } \\
\text { weight } \\
\boldsymbol{K}_{\boldsymbol{g}} \text {. }\end{array}$} \\
\hline & & & Mean & Range & & \\
\hline $\begin{array}{l}\text { Hyperthyroid } \\
\text { Normal } \\
\text { Overall euthyroid } \\
\text { Hypothyroid }\end{array}$ & $\begin{array}{l}29 \\
30 \\
53 \\
18\end{array}$ & $\begin{array}{r}7 \\
33 \\
25 \\
11\end{array}$ & $\begin{array}{l}43.7 \\
42.7 \\
44.9 \\
49.5\end{array}$ & $\begin{array}{l}(18-77) \\
(19-68) \\
(19-75) \\
(28-73)\end{array}$ & $\begin{array}{l}159.0 \\
160.8 \\
158.7 \\
158.2\end{array}$ & $\begin{array}{l}53.9 \\
66.1 \\
64.0 \\
61.6\end{array}$ \\
\hline
\end{tabular}

first 53 consecutive duplicate samples deviated $6.2 \pm 4.4$ per cent from the average of the two samples. The per cent, as well as absolute differences, tended to be greatest for high values, particularly those over $2.0 \mathrm{mg}$. per cent. Differences between the first samples and their duplicates analyzed after one to 77 days in the frozen state were not significant. Recovery of 10 to $60 \mu \mathrm{g}$. of dl- $\alpha$-tocopherol from serum or reconstituted dried human plasma in 16 determinations was $97.2 \pm 3.1$ per cent. Hydrogenation of vitamin $A$ and $\beta$-carotene was complete in 15 seconds. Crystalline cholesterol in amounts equivalent to serum concentrations of 0 to $1,200 \mathrm{mg}$. per cent did not modify the 15-second color density of the tocopherol standards. Iodide in concentrations of $1,000 \mu \mathrm{g}$. per cent modified the standard curve, but $100 \mu \mathrm{g}$. per cent did not. Also, $I^{121}$ labelled sodium iodide added to serum was not extracted into the hexane solvent. Thyroxine in concentrations up to $100 \mu \mathrm{g}$. per cent did not modify the color reaction.

Miscellaneous determinations. Basal metabolic rates were determined by the thyroid laboratory technicians using a Roth-Benedict apparatus. Protein bound iodine was determined by the method of Barker (25). The uptake of radioactive $I^{121}$ twenty-four hours after a 10 to 20 micro-

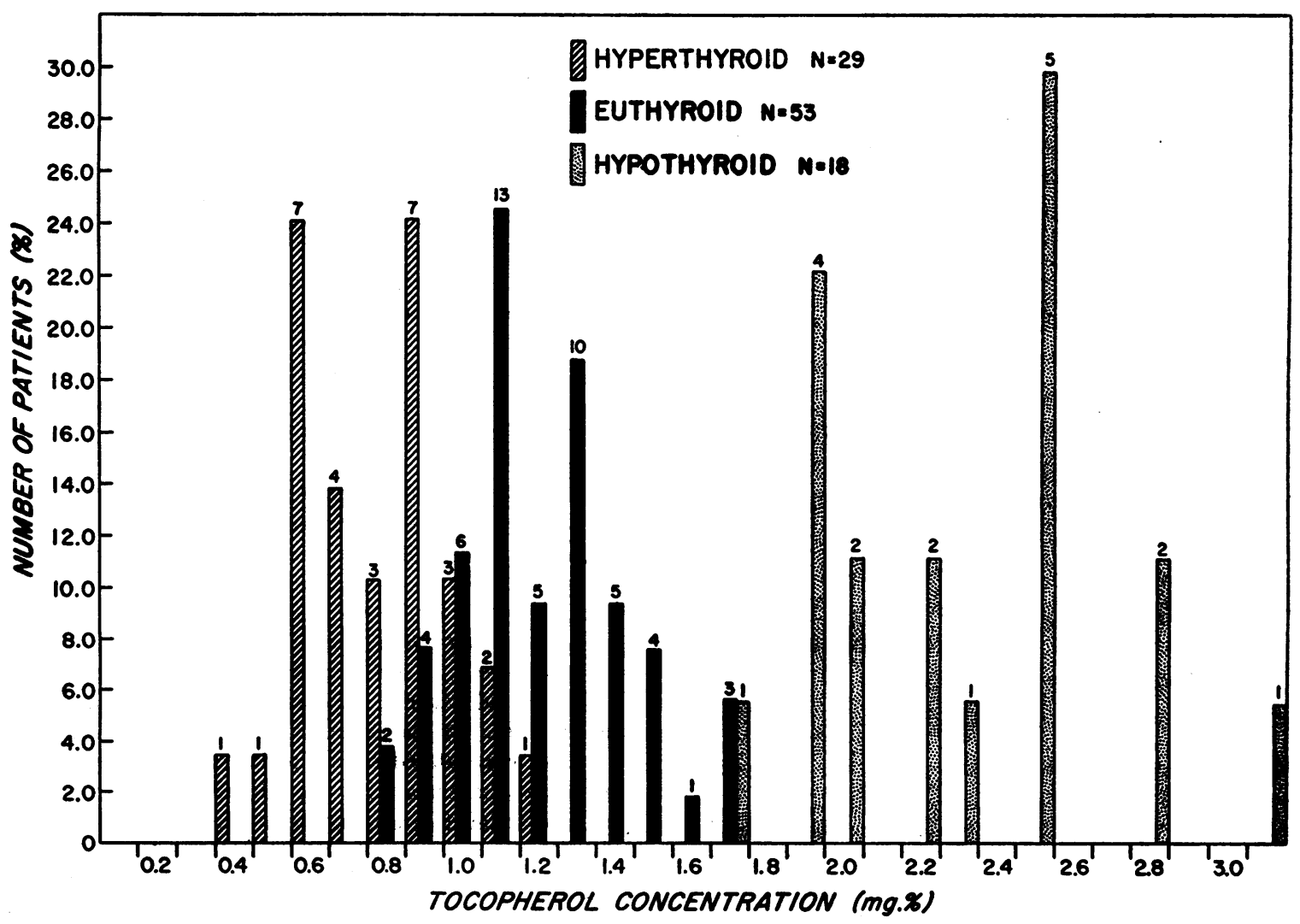

Fig. 1. Frequency Distribution of the Concentration of Tocopherols in the Serum of Patients Grouped According to Their State of Thyroid Function

Class intervals equal $0.1 \mathrm{mg}$. per cent. 
curie dose was determined with 3-scintillation detectors placed on a $30 \mathrm{~cm}$. diameter circle. The concentration of cholesterol in serum was determined in the hospital laboratory using the method of Bloor and Knudson (26). Blood samples for tocopherol and cholesterol determinations were drawn at random times in view of the apparent constancy of cholesterol (27-29) and tocopherol (30) levels throughout the day. The symbol \pm precedes the standard deviation within the observed population. A statement of significance implies a $P$ value of less than 0.001. Linear correlations of two variables are based on Pearson's product moment coefficient.

\section{RESULTS}

\section{Distribution of serum tocopherol concentrations in hyperthyroidism and hypothyroidism}

The mean tocopherol concentration in $29 \mathrm{pa}$ tients with active untreated Graves' disease was $0.74 \pm 0.20 \mathrm{mg}$. per cent, compared with a mean value of $1.20 \pm 0.22 \mathrm{mg}$. per cent for the 30 normals and $1.21 \pm 0.23 \mathrm{mg}$. per cent for the group of 53 patients in the euthyroid state. The 18 hypothyroid patients presented with a mean level of $2.29 \pm 0.38 \mathrm{mg}$. per cent. The differences between the hyperthyroid patients, hypothyroid patients and euthyroid group are all significant $(\mathrm{P}=<.001)$. The frequency distribution of tocopherol levels

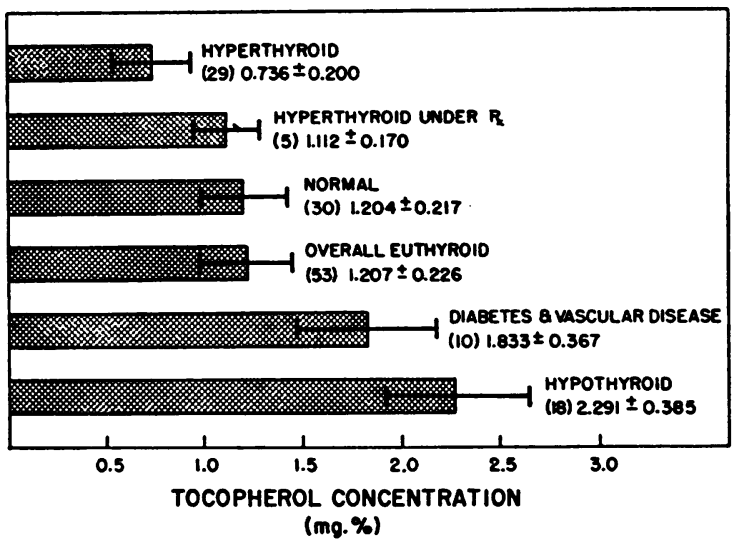

Fig. 2. The Mean Concentration of Tocopherols in the Serum of Individuals Grouped According to Metabolic State

The distance between the two short vertical bars represents, in each case, two standard deviations.

among these 100 patients is given in Figure 1, and the mean concentrations for the various populations in Figure 2. Five patients with active Graves' disease who had received treatment either in the form of iodides or antithyroid drugs within two weeks of the initial tocopherol determinations had serum tocopherol concentrations which were not significantly different from the euthyroid group.

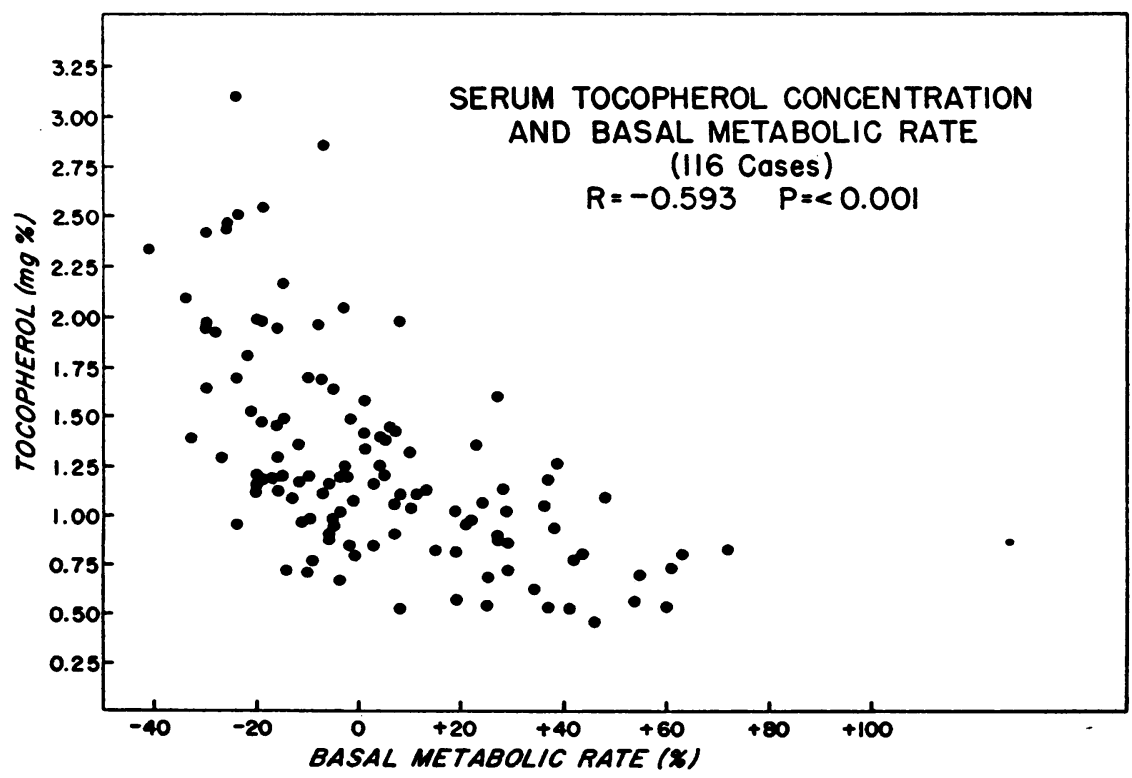

Fig. 3. Relationship Between Concentration of Tocopherols in Serum and Basal Metabolic Rate 


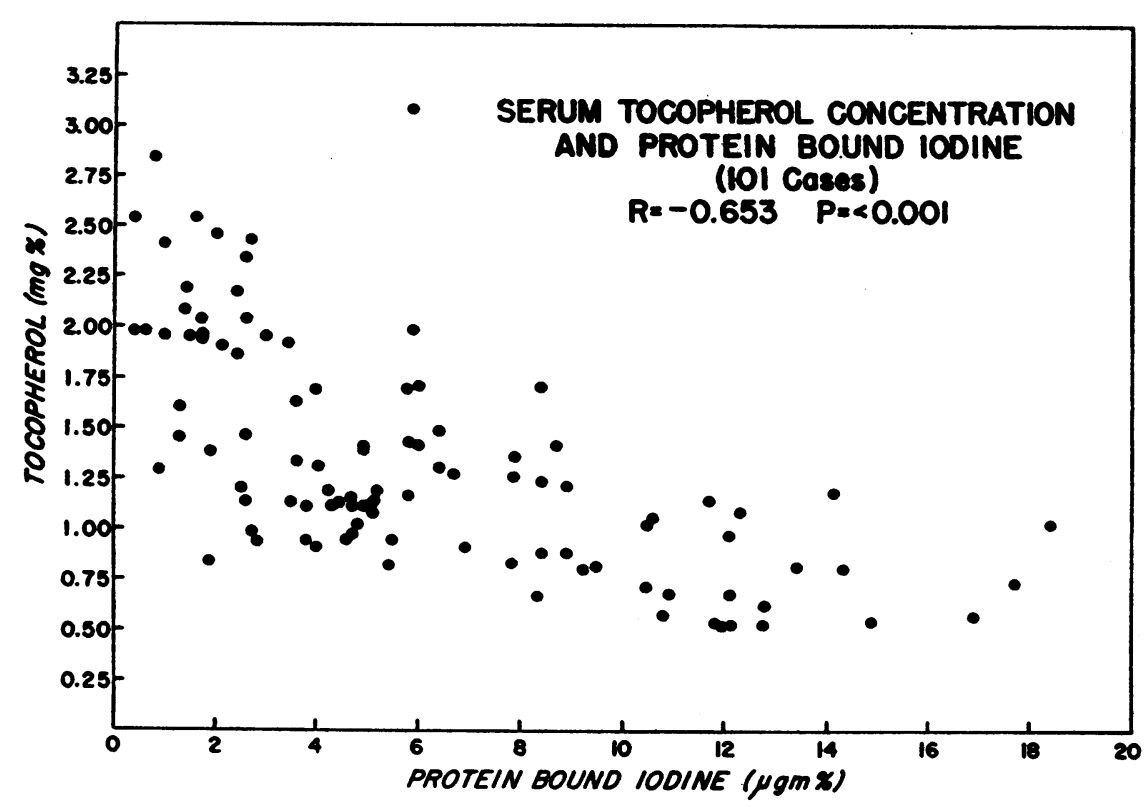

Fig. 4. Relationship Between Concentration of Tocopherols and Protein Bound Iodine in Serum of Subjects With and Without Thyroid Disease

2. Correlation between serum tocopherol level and metabolic state

Having defined low and high serum tocopherol levels in patients with hyperthyroidism and hypothyroidism, respectively, an attempt was made to appraise the extent to which the tocopherol con- centration parallels the metabolic state of the patient. In the absence of an accurate direct index of level of metabolism, the correlations between tocopherol level and basal metabolic rate, serum protein bound iodine (PBI) and 24-hour radioactive iodine uptake, respectively, were examined. Figure

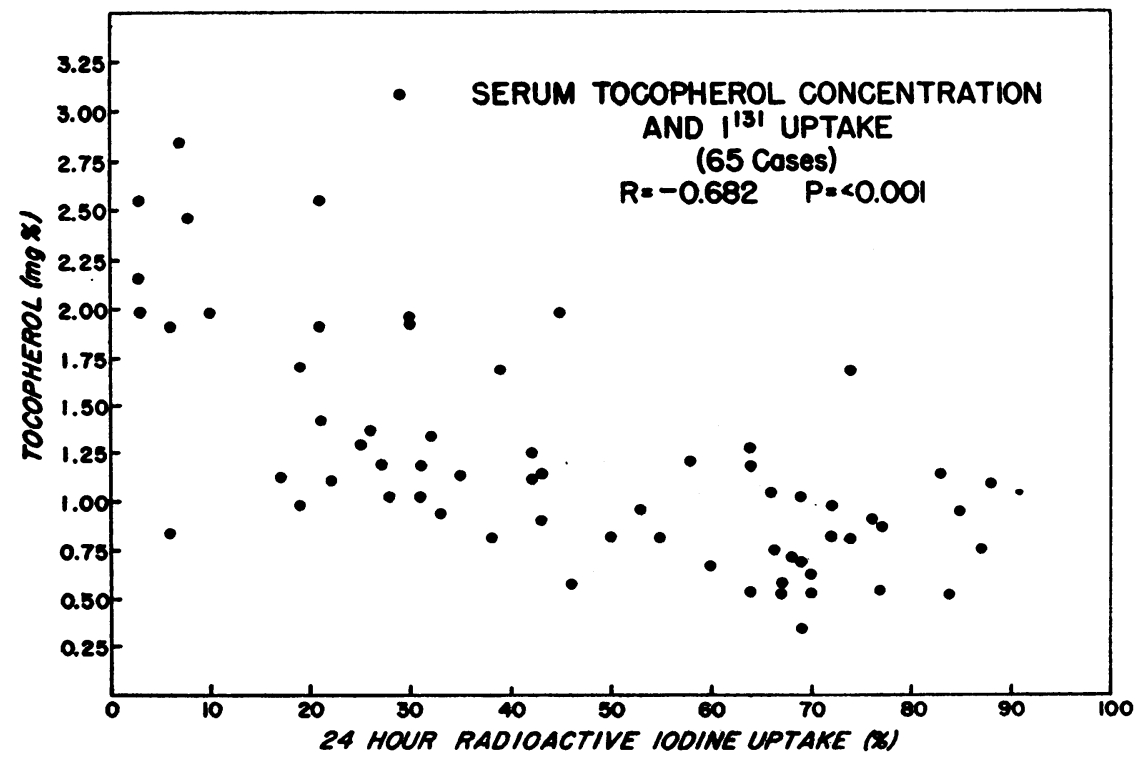

Fig. 5. Relationship Betwegen Concentration of Tocopherols in Serum and the 24-Hour Thyrotdal Uptake of $\mathrm{I}^{m}$ 


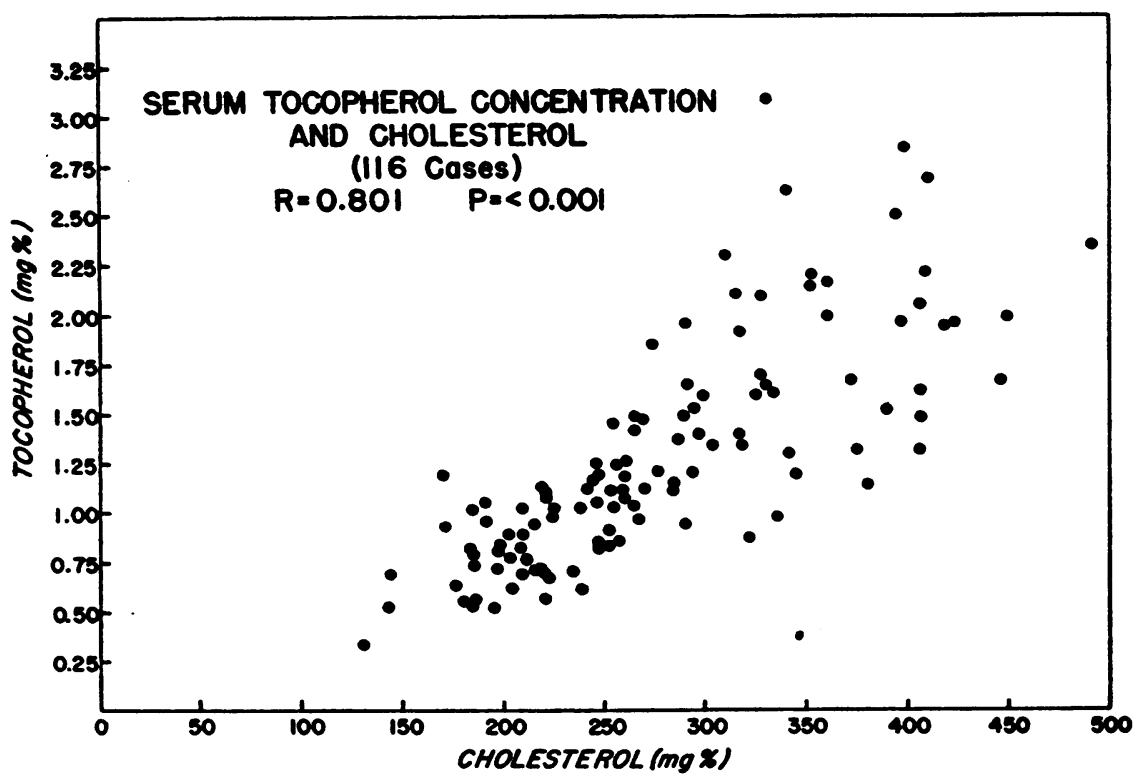

Fig. 6. Relationship Between the Concentrations of Tocopherols and Cholesterol. in the Serum

3 is the scattergram of all of the 116 instances in which tocopherol level and BMR were determined on the same day. The coefficient of correlation was -0.593 . The coefficient of correlation for 116 paired values of tocopherol and PBI was -0.653 (Figure 4), and for 65 pairs of simultaneous tocopherol determinations and 24-hour radioactive iodine uptake -0.682 (Figure 5 ).
" $Z$ " transformations of these coefficients indicate a probability of less than 0.001 in each case.

\section{Correlation between tocopherol and cholesterol concentrations in serum}

The fat solubility of tocopherols and the well established inverse relationship between metabolic level and serum lipid concentration, particularly

TABLE II

Correlation of serum tocopherol and serum cholesterol concentrations compared with correlation of serum tocopherol concentration with indices of thyroid function

\begin{tabular}{|c|c|c|c|c|c|c|c|c|c|c|}
\hline & \multicolumn{5}{|c|}{ Maximum pairs (all subjects) } & \multicolumn{5}{|c|}{$\begin{array}{l}\text { Hypo- and hyperthyroid subjects } \\
\text { under treatment }\end{array}$} \\
\hline & No. & "r"* & $\mathbf{z} \boldsymbol{\dagger}$ & $\frac{\Delta z}{\operatorname{SE\Delta }}$ & $\mathbf{P}$ & No. & "r" & $\mathbf{z}$ & $\frac{\Delta Z}{\operatorname{SE\Delta }}$ & $\mathbf{P}$ \\
\hline $\begin{array}{l}\text { Tocopherol and } \\
\text { cholesterol } \\
\text { compared with: }\end{array}$ & 116 & +0.801 & $1.102 \pm .0941$ & & & 56 & +0.790 & $1.071 \pm .1374$ & & \\
\hline $\begin{array}{l}\text { Tocopherol and } \\
\text { PBI }\end{array}$ & 101 & -0.653 & $0.780 \pm 1010$ & 2.331 & $\begin{array}{l}<0.02 \\
>0.01\end{array}$ & 56 & -0.717 & $0.902 \pm .1374$ & 0.871 & $>0.33$ \\
\hline $\begin{array}{l}\text { Tocopherol and } \\
\text { BMR }\end{array}$ & 116 & -0.593 & $0.682 \pm .0941$ & 3.158 & $\begin{array}{l}<0.005 \\
>0.001\end{array}$ & 56 & -0.736 & $0.941 \pm .1374$ & 0.205 & $>0.50$ \\
\hline $\begin{array}{l}\text { Tocopherol and } \\
\text { tracer } \ddagger\end{array}$ & 65 & -0.682 & $0.833 \pm .1270$ & 1.702 & $\begin{array}{l}<0.10 \\
>0.05\end{array}$ & & & Not analyzed $\$$ & & \\
\hline
\end{tabular}

* Pearson's product moment coefficient.

tFisher's "Z" transformation.

$\$$ Twenty-four-hour uptake of $I^{1 m}$.

Tracer data excluded because patients receiving treatment. 
TABLE III

Clinical and laboratory data and serum tocophorol concentrations in patients with untreated toxsic diff use goiter

\begin{tabular}{|c|c|c|c|c|c|c|c|c|c|c|c|c|c|}
\hline Pt. & Sex & Age & $\begin{array}{c}\text { Dura- } \\
\text { tion } \\
\text { mos. }\end{array}$ & Severity* & $\begin{array}{c}\text { Weight } \\
\text { loss } \\
K_{\mathbf{g}} .\end{array}$ & Weaknesst & $\begin{array}{c}\text { Height } \\
\text { cm. }\end{array}$ & $\begin{array}{c}\text { Weight } \\
\mathbf{K}_{\mathbf{g} .}\end{array}$ & $\underset{\%}{\text { BMR }}$ & $\begin{array}{c}\text { PBI } \\
\text { M\&. \% }\end{array}$ & $\begin{array}{l}24-\mathrm{hr} . \\
\text { I-13i } \\
\text { uptake }\end{array}$ & $\begin{array}{c}\text { Cholesterol } \\
\text { mg. \% }\end{array}$ & $\begin{array}{c}\text { Tocopherol } \\
\text { mg. \% }\end{array}$ \\
\hline $\begin{array}{l}\text { A. F. } \\
\text { B. G. } \\
\text { C. E. } \\
\text { C. T. } \\
\text { C. B. } \\
\text { C. T. } \\
\text { D. M. } \\
\text { D. A. } \\
\text { D. L. } \\
\text { D. M. } \\
\text { F. A. } \\
\text { F. D. } \\
\text { F. M. } \\
\text { G. C. } \\
\text { H. B. } \\
\text { H. M. } \\
\text { H. D. } \\
\text { H. M. } \\
\text { K. G. } \\
\text { K. B. } \\
\text { K. A. } \\
\text { L. E. } \\
\text { L. A. } \\
\text { M. N. } \\
\text { M. E. } \\
\text { P. M. } \\
\text { R. I. } \\
\text { R. D. } \\
\text { S. H. }\end{array}$ & $\begin{array}{l}F \\
F \\
F \\
M \\
F \\
M \\
F \\
F \\
F \\
F \\
F \\
F \\
F \\
F \\
F \\
F \\
F \\
F \\
F \\
F \\
F \\
F \\
F \\
F \\
F \\
F \\
F \\
F \\
F\end{array}$ & $\begin{array}{l}43 \\
41 \\
36 \\
64 \\
22 \\
31 \\
63 \\
54 \\
52 \\
35 \\
52 \\
31 \\
53 \\
52 \\
37 \\
40 \\
31 \\
38 \\
67 \\
25 \\
24 \\
38 \\
61 \\
18 \\
77 \\
49 \\
53 \\
52 \\
37\end{array}$ & $\begin{array}{r}5 \\
30 \\
9 \\
12 \\
4 \\
12 \\
36 \\
24 \\
24 \\
? \\
5 \\
12 \\
36 \\
6 \\
10 \\
3 \\
6 \\
12 \\
24 \\
3 \\
5 \\
6 \\
18 \\
24 \\
12 \\
12 \\
12 \\
84 \\
12\end{array}$ & $\begin{array}{c}++ \\
++ \\
+ \\
+++ \\
++ \\
+++ \\
++ \\
+++ \\
++ \\
++ \\
++ \\
+\end{array}$ & $\begin{array}{c}0 \\
8.2 \\
6.8 \\
5.4 \\
4.0 \\
11.4 \\
\vdots \\
\ddagger \\
4.1 \\
0.0 \\
3.6 \\
\ddagger \\
21.4 \\
\vdots \\
16.8 \\
9.1 \\
\vdots \\
\vdots \\
31.8 \\
3.6 \\
22.2 \\
\ddagger \\
36.4 \\
\vdots \\
\ddagger \\
0.0 \\
4.1 \\
0.0 \\
8\end{array}$ & $\begin{array}{c}+ \\
+ \\
+ \\
+ \\
0 \\
+ \\
+ \\
+ \\
+ \\
+ \\
++ \\
+ \\
++ \\
0 \\
+ \\
+ \\
+ \\
+ \\
++ \\
++ \\
+ \\
++ \\
+\end{array}$ & $\begin{array}{l}156.2 \\
166.5 \\
154.7 \\
162.8 \\
172.3 \\
168.8 \\
150.5 \\
154.3 \\
163.4 \\
146.0 \\
165.1 \\
157.1 \\
156.5 \\
157.4 \\
161.1 \\
162.7 \\
154.7 \\
161.5 \\
161.7 \\
157.4\end{array}$ & $\begin{array}{l}52.9 \\
55.7 \\
36.1 \\
59.8 \\
69.7 \\
48.4 \\
49.2 \\
41.8 \\
66.9 \\
47.2 \\
75.7 \\
57.2 \\
45.1 \\
55.6 \\
56.1 \\
51.8 \\
47.6 \\
34.1 \\
47.5 \\
67.9 \\
43.2 \\
42.8 \\
76.2 \\
40.0 \\
89.0 \\
53.9 \\
47.3 \\
52.9\end{array}$ & $\begin{array}{l}+28 \\
+61 \\
+60 \\
+44 \\
+63 \\
+54 \\
+42 \\
+29 \\
+21 \\
+27 \\
+37 \\
+25 \\
+36 \\
+22 \\
+46 \\
+48 \\
+29 \\
+19 \\
+15 \\
+41 \\
+72 \\
+55 \\
+4 \\
+34 \\
+8 \\
+19\end{array}$ & $\begin{array}{r}11.7 \\
14.9 \\
9.2 \\
14.3 \\
16.9 \\
17.7 \\
\\
\\
8.9 \\
12.1 \\
11.8 \\
10.6 \\
12.1 \\
12.3 \\
10.5 \\
10.8 \\
\\
5.4 \\
12.0 \\
13.4 \\
9.8 \\
12.1 \\
8.3 \\
12.8 \\
12.8 \\
10.5\end{array}$ & $\begin{array}{l}83 \\
66 \\
77 \\
55 \\
74 \\
46 \\
87 \\
68 \\
85 \\
77 \\
70 \\
64 \\
66 \\
79 \\
69 \\
88 \\
68 \\
67 \\
90 \\
50 \\
84 \\
78 \\
72 \\
51 \\
69 \\
60 \\
70 \\
67 \\
69\end{array}$ & $\begin{array}{l}380 \\
\\
183 \\
198 \\
183 \\
210 \\
211 \\
257 \\
\\
321 \\
185 \\
182 \\
264 \\
\\
130 \\
221\end{array}$ & $\begin{array}{l}1.14 \\
0.74 \\
0.54 \\
0.80 \\
0.81 \\
0.57 \\
0.75 \\
0.86 \\
0.96 \\
0.87 \\
0.52 \\
0.53 \\
1.04 \\
0.98 \\
0.34 \\
1.09 \\
0.72 \\
0.57 \\
0.82 \\
0.82 \\
0.52 \\
0.64 \\
0.82 \\
0.48 \\
0.68 \\
0.67 \\
0.62 \\
0.52 \\
0.94\end{array}$ \\
\hline
\end{tabular}

* One plus: mild; two plus: moderately severe; three plus : severe.

+0 : weakness not a significant symptom; + : weakness present but not a dominant feature; $+++:$ weakness subjectively and objectively marked and labelled "thyrotoxic myopathy."

† Lost weight, but amount unspecified.

\$ained $3.2 \mathrm{Kg}$.

Atrophy of humeroscapular muscles.

cholesterol, prompted inquiry into the manner in which tocopherol and cholesterol concentrations were correlated. The coefficient of correlation was +0.801 for 116 paired values spanning a range of 130 to $492 \mathrm{mg}$. per cent for cholesterol and 0.34 to $3.07 \mathrm{mg}$. per cent for tocopherol (Figure 6). This degree of correlation is greater than for maximum paired correlations of serum tocopherol concentration with the PBI, BMR, and possibly the 24-hour thyroidal uptake of $\mathrm{I}^{181}$ (Table II). In patients with hyperthyroidism and hypothyroidism under treatment, 56 sets of simultaneous tocopherol, BMR, PBI, and cholesterol determinations disclosed no significant difference between the correlations of tocopherol concentration with each of the other variables (Table II).

\section{Correlation between serum tocopherol concen- tration and obesity or leanness}

A critical difference between thyrotoxic, euthyroid, and hypothyroid groups is the body weight, thyrotoxic subjects generally being underweight, hypothyroid patients tending to obesity. To test the bearing of weight status on tocopherol levels, members of the euthyroid group were ranked as to per cent departure from standard weight $(31,32)$ for the given height, neglecting age. The range of deviation from standard weight was -29 per cent to +97 per cent. Rank correlation with tocopherol concentration was not significant (" $r$ " $=+0.173$ ), indicating that body weight does not in and of itself account for the group differences. In addition, ten subjects presenting a clinical picture suggestive of possible thyrotoxicity but shown by test to be in a euthyroid state, had a mean tocopherol concentration of $1.240 \pm 0.32 \mathrm{mg}$. per cent. This group included one patient with a $30 \mathrm{Kg}$. weight loss achieved by an 800 to 1,000 calorie diet over a 19-month period. At the end of this period, the tocopherol level was $1.07 \mathrm{mg}$. per cent. Other cases in point are those of an uncontrolled diabetic who lost 9.1 
TABLE IV

Response of serum tocopherol concentrations to treatment of hyperthyroidism

\begin{tabular}{|c|c|c|c|c|c|c|c|c|c|c|c|}
\hline \multirow[b]{2}{*}{ Pt. } & \multirow[b]{2}{*}{$\mathbf{R x}$. } & \multirow{2}{*}{$\begin{array}{l}\text { Interval } \\
\text { since Rx. } \\
\text { (weeks) }\end{array}$} & \multirow{2}{*}{$\begin{array}{c}\text { Status* } \\
\text { post- } \\
\text { Rx. }\end{array}$} & \multicolumn{2}{|c|}{$\underset{\%}{\text { BMR }}$} & \multicolumn{2}{|c|}{$\underset{\text { mg. \% }}{\text { PBI }}$} & \multicolumn{2}{|c|}{$\begin{array}{c}\text { Cholesterol } \\
\text { mg. \% }\end{array}$} & \multicolumn{2}{|c|}{$\begin{array}{l}\text { Tocopherol } \\
\text { mg. \% }\end{array}$} \\
\hline & & & & $\begin{array}{l}\text { Pre- } \\
\mathbf{R x} \text {. }\end{array}$ & $\begin{array}{l}\text { Post- } \\
\mathbf{R x} \text {. }\end{array}$ & $\begin{array}{l}\text { Pre- } \\
\text { Rx. }\end{array}$ & $\begin{array}{l}\text { Post- } \\
\text { Rx. }\end{array}$ & $\begin{array}{l}\text { Pre- } \\
\text { Rx. }\end{array}$ & $\begin{array}{l}\text { Post- } \\
\text { Rx. }\end{array}$ & $\begin{array}{l}\text { Pre- } \\
\text { Rx. }\end{array}$ & $\begin{array}{l}\text { Post- } \\
\text { Rx. }\end{array}$ \\
\hline $\begin{array}{l}\text { B. G. } \\
\text { C. T. } \\
\text { D. A. } \\
\text { H. D. } \\
\text { H. M. } \\
\text { P. M. }\end{array}$ & $\begin{array}{l}\text { I-131 } \\
\text { MET } \\
\text { I-131 } \\
\text { KClO } \\
\text { MET } \\
\text { I-131 }\end{array}$ & $\begin{array}{r}11 \\
7 \\
7 \\
13 \\
15 \\
17\end{array}$ & $\begin{array}{l}\mathbf{H} \\
\mathbf{H} \\
\mathbf{H} \\
\mathbf{H} \\
\mathbf{H} \\
\mathbf{H}\end{array}$ & $\begin{array}{l}+61 \\
+54 \\
+29 \\
+29 \\
+19 \\
-4\end{array}$ & $\begin{array}{l}-15 \\
+27 \\
-21 \\
-22 \\
-16 \\
-24\end{array}$ & $\begin{array}{r}16.9 \\
10.5 \\
10.8 \\
8.3\end{array}$ & $\begin{array}{l}2.4 \\
1.3 \\
2.3 \\
1.0 \\
1.3 \\
4.0\end{array}$ & $\begin{array}{l}210 \\
257 \\
\\
222\end{array}$ & $\begin{array}{l}360 \\
334 \\
390 \\
423 \\
254 \\
327\end{array}$ & $\begin{array}{l}0.74 \\
0.57 \\
0.86 \\
0.72 \\
0.57 \\
0.67\end{array}$ & $\begin{array}{l}2.16 \\
1.60 \\
1.51 \\
1.95 \\
1.45 \\
1.68\end{array}$ \\
\hline $\begin{array}{l}\text { C. B. } \\
\text { C. E. } \\
\text { D. M. } \\
\text { F. M. } \\
\text { G. C. } \\
\text { H. B. } \\
\text { K. G. } \\
\text { L. A. } \\
\text { R. I. } \\
\text { S. H. }\end{array}$ & $\begin{array}{l}\text { MET } \\
\text { I-131 } \\
\text { MET } \\
\text { I-131 } \\
\text { I-131 } \\
\text { I-131 } \\
\text { I-131 } \\
\text { I-131 } \\
\text { I-131 } \\
\text { KC1O }\end{array}$ & $\begin{array}{r}7 \\
30 \\
7 \\
22 \\
10 \\
8 \\
17 \\
10 \\
7 \\
11\end{array}$ & $\begin{array}{l}\mathbf{E} \\
\mathbf{E} \\
\mathbf{E} \\
\mathbf{E} \\
\mathbf{E} \\
\mathbf{E} \\
\mathbf{E} \\
\mathbf{E} \\
\mathbf{E}\end{array}$ & $\begin{array}{l}+63 \\
+60 \\
+27 \\
+36 \\
+22 \\
+46 \\
+72 \\
+34 \\
+19\end{array}$ & $\begin{array}{l}+3 \\
-7 \\
+11 \\
-5 \\
-6 \\
-15 \\
\\
-20\end{array}$ & $\begin{array}{r}11.7 \\
14.9 \\
8.9 \\
10.6 \\
12.1 \\
\\
\\
\end{array}$ & $\begin{array}{l}7.3 \\
4.7 \\
4.3 \\
3.6 \\
5.8 \\
6.4 \\
3.8 \\
2.7 \\
5.1 \\
4.4\end{array}$ & $\begin{array}{l}183 \\
183 \\
321 \\
264 \\
\\
130 \\
\\
247 \\
238 \\
215\end{array}$ & $\begin{array}{l}284 \\
252 \\
330 \\
244 \\
290 \\
270 \\
372 \\
283 \\
241\end{array}$ & $\begin{array}{l}0.81 \\
0.54 \\
0.87 \\
1.04 \\
0.98 \\
0.34 \\
0.82 \\
0.82 \\
0.62 \\
0.94\end{array}$ & $\begin{array}{l}1.16 \\
1.11 \\
1.11 \\
1.63 \\
1.16 \\
1.49 \\
1.12 \\
1.66 \\
1.13 \\
1.12\end{array}$ \\
\hline $\begin{array}{l}\text { C. T. } \\
\text { D. M. } \\
\text { F. D. } \\
\text { K. A. } \\
\text { M. N. }\end{array}$ & $\begin{array}{l}\text { MET } \\
\text { I-131 } \\
\text { I-131 } \\
\text { PTU } \\
\text { I-131 }\end{array}$ & $\begin{array}{r}3 \\
8 \\
9 \\
4 \\
15\end{array}$ & $\begin{array}{l}T \\
T \\
T \\
T \\
T\end{array}$ & $\begin{array}{l}+44 \\
+42 \\
+25 \\
+41 \\
+55\end{array}$ & $\begin{array}{r}+19 \\
+55 \\
+29\end{array}$ & $\begin{array}{r}9.2 \\
17.7 \\
11.8 \\
12.0 \\
9.8\end{array}$ & $\begin{array}{r}8.4 \\
20.0 \\
10.9 \\
11.3\end{array}$ & $\begin{array}{l}198 \\
211 \\
182 \\
137 \\
169\end{array}$ & $\begin{array}{l}198 \\
234\end{array}$ & $\begin{array}{l}0.80 \\
0.75 \\
0.53 \\
0.52 \\
0.48\end{array}$ & $\begin{array}{l}0.82 \\
0.72 \\
0.68 \\
1.01 \\
0.64\end{array}$ \\
\hline
\end{tabular}

* $\mathrm{H}$ : hypothyroid.

E: euthyroid.

T: still toxic.

† Methimazole.

† Propylthiouracil.

$\mathrm{Kg}$. in 3 months and had a serum tocopherol concentration of $1.90 \mathrm{mg}$. per cent, and one patient with an anorexia nervosa-like syndrome whose tocopherol level was $1.21 \mathrm{mg}$. per cent notwithstanding an $18.2 \mathrm{Kg}$. weight loss over a 7-month period. Furthermore, analysis of the clinical features of the thyrotoxic group, vide infra, disclosed low serum tocopherols in patients who were grossly obese.

\section{Relation between clinical status and tocopherol levels among thyrotoxic patients}

Analysis of the thyrotoxic patients as to age, sex, duration of illness, extent of weight loss, clinical estimate of the severity of thyrotoxicity and prominence of muscular weakness yielded no clue upon which to base predictions of tocopherol level with complete confidence. However, from inspection of Table III it appears that, in general, patients with severe Graves' disease have the lowest levels ( 0.3 to $0.8 \mathrm{mg}$. per cent), while those with mild or relatively asymptomatic forms of the disease tend to values approaching normal, e.g., 0.8 to $1.1 \mathrm{mg}$. per cent. Noteworthy exceptions to these generalizations are patient $\mathrm{L}$. A. with very severe disease and a tocopherol concentration of 0.82 , and patient $R$. I. who had a level of 0.62 but was essentially asymptomatic. It is clear that weight loss as such is not the critical variable. Thus, very low values of $0.52,0.67,0.62$, and 0.52 were observed in patients F. A., P. M., R. I., and $R$. D., respectively, in none of whom weight loss was striking. Indeed, of these patients F. A. and P. M. were grossly obese, weighing 75.7 and $89.0 \mathrm{Kg}$., respectively. In three thyrotoxic individuals (C. E., M. E., and R. D.), muscular weakness and atrophy were dominant clinical features. All three had very low tocopherol levels, 0.54, 0.68 , and $0.52 \mathrm{mg}$. per cent, respectively. One patient, M. N., with distinct shoulder girdle atrophy which had no apparent explanation other than her thyrotoxic state, was quite well preserved as to fat deposits (weight, 76.2 Kg.) and had a low serum tocopherol of $0.48 \mathrm{mg}$. per cent. 
TABLE V

Response of serum tocopherol concentration to treatment of hypothyroidism

\begin{tabular}{|c|c|c|c|c|c|c|c|c|c|c|}
\hline \multirow[b]{2}{*}{ Pt. } & \multirow[b]{2}{*}{ Rx. } & \multirow{2}{*}{$\begin{array}{l}\text { Duration } \\
\text { of } \mathbf{R x} \text {. } \\
\text { (weeks) }\end{array}$} & \multicolumn{2}{|c|}{$\underset{\%}{\text { BMR }}$} & \multicolumn{2}{|c|}{$\underset{\%}{\mathbf{P B I}}$} & \multicolumn{2}{|c|}{$\begin{array}{c}\text { Cholesterol } \\
\text { mg. \% }\end{array}$} & \multicolumn{2}{|c|}{$\begin{array}{l}\text { Tocopherol } \\
\text { mg. \% }\end{array}$} \\
\hline & & & $\begin{array}{l}\text { Pre- } \\
\text { Rx. }\end{array}$ & $\begin{array}{c}\text { Post- } \\
\text { Rx. }\end{array}$ & $\begin{array}{l}\text { Pre- } \\
\text { Rx. }\end{array}$ & $\begin{array}{c}\text { Post- } \\
\text { Rx. }\end{array}$ & $\begin{array}{l}\text { Pre- } \\
\text { Rx. }\end{array}$ & $\begin{array}{c}\text { Post- } \\
\text { Rx. }\end{array}$ & $\begin{array}{l}\text { Pre- } \\
\text { Rx. }\end{array}$ & $\begin{array}{c}\text { Post- } \\
\text { Rx. }\end{array}$ \\
\hline $\begin{array}{l}\text { B. A. } \\
\text { D. A. } \\
\text { G. D. } \\
\text { H. D. } \\
\text { P. G. }\end{array}$ & $\begin{array}{l}\text { T-3* } \\
\text { T-3 Ac. }{ }^{*} \\
\text { T-3 } \\
\text { T-3 } \\
\text { D.T.f }\end{array}$ & $\begin{array}{c}14 \\
1 \frac{1}{2} \\
12 \\
6 \\
6\end{array}$ & $\begin{array}{l}-21 \\
-30 \\
-26 \\
-22 \\
-41\end{array}$ & $\begin{array}{r}-2 \\
+2 \\
-4 \\
+25 \\
-10\end{array}$ & $\begin{array}{l}3.4 \\
1.0 \\
2.7 \\
1.0 \\
2.6\end{array}$ & $\begin{array}{l}0.4 \\
2.1\end{array}$ & $\begin{array}{l}335 \\
339 \\
410 \\
423 \\
491\end{array}$ & $\begin{array}{l}251 \\
418 \\
184 \\
220 \\
293\end{array}$ & $\begin{array}{l}1.92 \\
2.42 \\
2.43 \\
1.95 \\
2.34\end{array}$ & $\begin{array}{l}0.83 \\
1.48 \\
1.01 \\
0.69 \\
1.20\end{array}$ \\
\hline
\end{tabular}

${ }^{*} \mathrm{~T}-3=$ dl-triiodothyronine.

T -3 Ac. = triiodothyroacetic acid.

$\mp$ D.T. = desiccated thyroid.

\section{Response of tocopherol concentration to change in metabolic state}

In 21 of the 29 thyrotoxic patients, determinations were available after treatment with radioactive iodine (13 cases) or antithyroid drugs (8 cases). Ten of the 21 follow-up determinations were made when the patients had reached a euthyroid state, and, in 6 instances, after progression to mild to marked hypothyroidism. Of the remaining 5 patients who were still thyrotoxic, 3 were definitely improved. With the exception of the two patients who were unchanged clinically after treatment (C. T. and D. M.), there was a rise in tocopherol level in response to correction of the hyperthyroid state. As noted in Table IV, this ranged from a minimum of an 18 per cent increase in patient G. C. who had a normal level to begin with, to a 340 per cent increase 8 weeks after $I^{131}$ treatment and return to the euthyroid state in patient $\mathrm{H}$. B.

The responses of 5 hypothyroid patients to treatment with thyroid hormones are recorded in Table $\mathrm{V}$ and portrayed graphically in Figure 7. In each case there was a definite fall in the serum tocopherol concentration to normal levels, or, in the one case in which the patient became thyrotoxic on treatment with dl-triiodothyronine (H. D.), to subnormal levels. The acuteness of the drop in tocopherol concentration is illustrated in Figure 8, which depicts the course of one patient with classical, spontaneous myxedema during the daily intravenous administration of triiodothyroacetic acid. ${ }^{2}$

\footnotetext{
2 Prepared by Dr. Rosalind Pitt-Rivers. The author appreciates the permission of Dr. Jacob Lerman to report these data.
}

In both thyrotoxic and hypothyroid groups, swings in tocopherol level corresponding to metabolic state were paralleled by changes in the concentration of serum cholesterol. This relationship was established in the preceding analysis in which a coefficient of correlation of +0.801 was noted for all pairs. The imperfections in this correlation are of special interest, as in the case of the above cited patient treated with triiodothyroacetic acid, whose serum cholesterol rose with restoration of metabolism to normal while the tocopherol concentration fell (Figure 8). Conversely, in thyrotoxic patient D. M., an initial abnormally high serum cholesterol level decreased upon return to a normal metabolic state and tocopherol concentration.

\section{DISCUSSION}

These observations indicate a strong inverse relationship between levels of thyroid function and the concentration of total free tocopherols in serum. This disagrees with the stated conclusions of a recent study (33) of 16 individuals with suspected thyroid dysfunction in whom no such correlation was noted. However, low tocopherol levels were noted in 3 out of 8 patients with basal metabolic rates of +10 or over, and in 2 of these 3 cases, increases in tocopherol concentration were observed during medical treatment of hyperthyroidism. It is likely that expansion of this series and application of discriminating tests of thyroid function would have yielded conclusions in keeping with those of the present report. The report of a high level in one hypothyroid child (34) is in accordance with the observations reported here. 


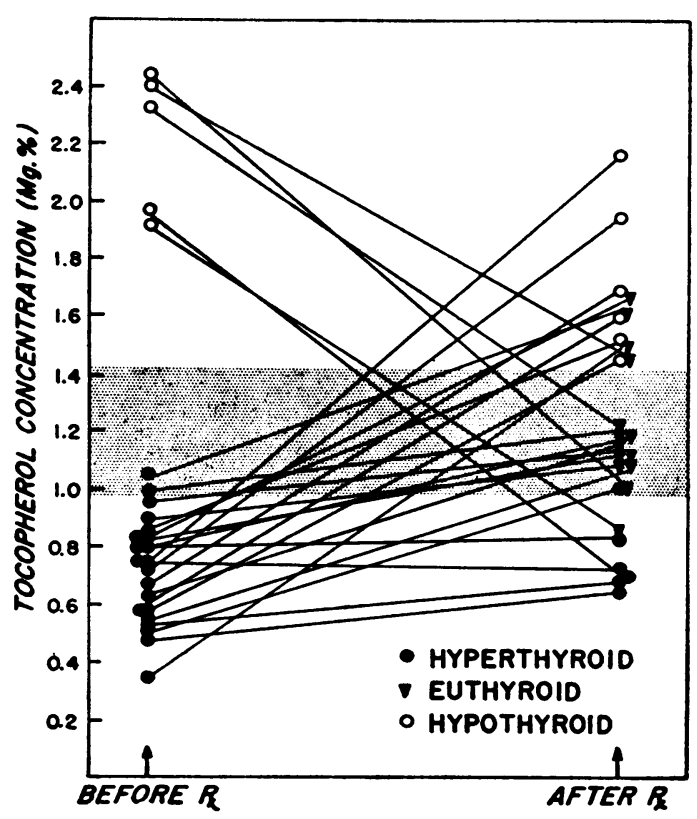

Fig. 7. Graphic Composite of Changes in ConCEntration of Serum TOCOPherols in Hypo- and HyPERThyroid Patients under Treatment

Normal range of tocopherol concentration (2 s.d.) is indicated by stippled zone.

The mean concentration of tocopherol in the sera of thyrotoxic patients is significantly low by normal standards set in all studies in which the method of Quaife and Harris was used (23, $35-40)$, as well as in relation to the internal controls. In the present series, serum levels of more than $1.2 \mathrm{mg}$. per cent rule out untreated Graves' disease, and a concentration of less than $1.7 \mathrm{mg}$. per cent is inconsistent with the diagnosis of hypothyroidism. Since low serum tocopherol levels occur in humans with absorption defects $(35,41)$, non-specific under-nutrition (36), and kwashiorkor (42), it is conceivable that low values observed in the thyrotoxic group relate to a deficit in absorption or diet. These are unlikely major factors in view of the isocaloric status of some patients, the lack of correlation between tocopherol level and weight, and the absence of steatorrhea and stigmata of other vitamin deficiencies. Similarly, low levels observed in some patients with liver disease $(40,43)$ raise the possibility that the thyrotoxic effect is mediated via deleterious influences on liver function. This mechanism cannot be excluded, but is not likely without more obvious marks of hepatic insufficiency associated

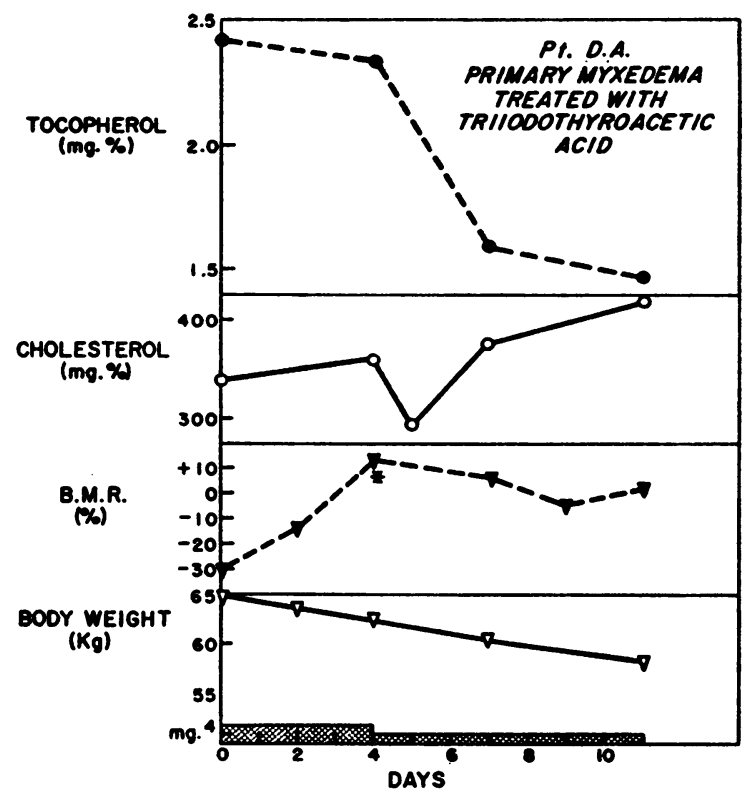

Fig. 8. The Response of the Serum Tocopherol Concentration Related to Cholesterol Level, BMR, and Weight in a Patient with Primary Myxedema Treated with Triodothyroacetic Acid

The asterisk indicates technically unsatisfactory determination of the BMR on the 4th day.

with cases of liver disease in which low tocopherol levels were found.

Strong positive correlation between concentrations of total cholesterol and tocopherols in serum shows that the fat-soluble tocopherols share the reciprocal relationship of serum lipid concentrations and levels of thyroid activity (44-46). On the other hand, alteration of tocopherol concentration with the total lipid compartment or one or more of its components is obviously not critically or uniquely related to thyroid function in view of hypertocopherolemia with various hypercholesterolemic disorders (41), and the rise in serum tocopherol levels in pregnancy (39), and in patients with diabetes mellitus who have high serum cholesterol concentrations (47). This general close association of tocopherol levels with concentrations of cholesterol in serum is borne out by greater correlation between cholesterol and tocopherol levels than between specific indices of thyroid function and tocopherol levels in the overall population sampled.

Occasional dissociation of cholesterol and tocopherol concentrations is of theoretical interest, 
and is pertinent to the possible usefulness of the serum tocopherol concentration as a laboratory adjunct in appraising metabolic state. Where thyroid activity appears to dictate the rate of synthesis as well as the degradation and excretion of cholesterol $(18,48)$, it is not surprising that cholesterol levels are occasionally elevated in hyperthyroidism (as in cases A. F. and D. M.) or that cholesterol concentration rises rather than falls during acute correction of hypothyroidism (as in case D. A. cited in Figure 8). Regulation of tocopherol concentration, on the other hand, would be determined primarily by intake, absorption, and rate of disposal without a component of synthesis in the equilibrated state. These examples of discrepancy between cholesterol and tocopherol concentration argue against the possibility that the observed changes are actually determined by the cholesterol content of serum.

It is impossible on the basis of serum concentration of tocopherols alone to estimate total tocopherol stores, aberrations in their metabolism, or the physiologic significance, if any, of the changes observed. It is fair, however, by analogy with low tocopherol levels in tocopherol depleted animals (49) and the fate of other metabolites in hyperthyroidism, to speculate that the low serum levels reported here reflect accelerated degradation of body tocopherol stores. Direct demonstration that this is so waits upon turnover studies or measurement of the total daily excretion of end products of tocopherol metabolism (50). Without such data one cannot exclude the possibility that the changes in tocopherol concentration reflect a direct effect of metabolic state on transport of tocopherols in serum, or an indirect one mediated by alterations in other lipids. Similarly, the physiologic impact of a depleted tocopherol supply must be appraised in terms of effects of tocopherol on the course of the thyrotoxic muscle lesion. In this connection, beneficial effects of long term therapy with oral tocopherols have been reported in 4 of 6 patients with Graves' disease (51). On the other hand, in an acute experiment with one subject, two days of treatment with tocopherols, including the phosphate ester intravenously, was accompanied by increased thyrotoxicity and weakness (52). However, the nonspecific inhibition of many enzyme systems by the phosphate (15), in a fashion seemingly unrelated to the vitamin action of tocopherol, could account for the adverse effects noted in this case.

There is no recognized lesion in man comparable to any of the tocopherol deficiency syndromes of animals, even in the aforementioned disorders in which low tocopherol levels have been shown. However, the hypermetabolism and possible increased tocopherol requirement of patients with toxic diffuse goiter results in a unique state. It remains reasonable to suggest that the thyrotoxic patient may provide the situation par excellence in which to find a human tocopherol deficiency state expressed as an acute reversible muscular dystrophy.

\section{CONCLUSIONS}

The concentration of total free tocopherols in serum is inversely related to the level of thyroid function in patients with thyroid disease. In toxic diffuse goiter, the concentrations are lowest among patients with severe disease, but emaciation as such is not a critical variable. Abnormalities in serum tocopherol content of thyrotoxic and hypothyroid patients generally parallel alterations in cholesterol level and are uniformly reversed upon restoration of normal metabolic state. Tocopherol concentrations are not critically correlated with clinical estimates of the extent of muscle disease in individual patients. Nonetheless, the possibility that human thyrotoxic myopathy is the analogue of vitamin $\mathrm{E}$ deficiency muscular dystrophy in animals merits further consideration.

\section{ACKNOWLEDGMENTS}

The author is indebted to Mr. Harris P. Goldberg for his able assistance, to Mrs. Peter Winchell for help with the statistical analyses, and to Dr. John B. Stanbury and the members of the Thyroid Clinic of the Massachusetts General Hospital for advice and criticism.

\section{Addendum}

Since submission of this manuscript, there has appeared a report of low tocopherol concentrations in the plasma of 6 hyperthyroid patients and high levels in 10 hypothyroid individuals compared with the control group of 7 normal subjects. (Costa, A., Cetini, G., Monteferrario, P., and Volterrani, O., Sulle possibili interferenze della Vitamina $\mathrm{E}$ con la struttura e la funzionalità tiroidea. Vitamina E : Atti del terzo Congresso Internazio- 
nale Venezia 1955. Verona, Valdonega, 1956, p. 233.)

\section{REFERENCES}

1. Adams, R. D., Neuromuscular System. Werner's The Thyroid, New York, Hoeber, 1955, p. 561.

2. Askanazy, M., Pathologisch-anatomische Beiträge zur Kenntniss des Morbus Basedowii, insbesondere über die dabei auftretende Muskelerkrankung. Deut. Arch. Klin. Med., 1898, 61, 118.

3. Shaffer, $P$., The excretion of kreatinin and kreatin in health and disease. Am. J. Physiol., 1908, 23, 1.

4. Shaffer, P. A., Observations on creatine and creatinine. J. Biol. Chem., 1914, 18, 525.

5. Wang, E., Clinical and experimental investigations on creatine metabolism. Acta med. Scandinav. 1939, Suppl. 105, 1.

6. Tierney, N. A., and Peters, J. P., The mode of excretion of creatine and creatine metabolism in thyroid disease. J. Clin. Invest., 1943, 22, 595.

7. Goettsch, M., and Brown, E. F., Muscle creatine in nutritional muscular dystrophy of the rabbit. J. Biol. Chem., 1932, 97, 549.

8. Victor, J., Metabolic and irritability changes in nutritional myopathy of rabbits and ducks. Am. J. Physiol., 1934, 108, 229.

9. Mackenzie, C. G., and McCollum, E. V., The cure of nutritional muscular dystrophy in the rabbit by alpha-tocopherol and its effect on creatine metabolism. J. Nutrition, 1940, 19, 345.

10. Houchin, O. B., and Mattill, H. A., The oxygen consumption, creatine, and chloride content of muscles from vitamin E-deficient animals as influenced by feeding $\alpha$-tocopherol. J. Biol. Chem., 1942, 146, 301.

11. Kaunitz, H., and Pappenheimer, A. M., Oxygen consumption in vitamin $\mathrm{E}$ deficiency. Am. J. Physiol., 1943, 138, 328.

12. Lardy, H. A., and Feldott, G., Metabolic effects of thyroxine in vitro. Ann. New York Acad. Sc., 1951, 54, 636.

13. Hoch, F. L., and Lipmann, F., The uncoupling of respiration and phosphorylation by thyroid hormones. Proc. Nat. Acad. Sc., 1954, 40, 909.

14. Maley, G. F., and Lardy, H. A., Efficiency of phosphorylation in selected oxidations by mitochondria from normal and thyrotoxic rat livers. J. Biol. Chem., 1955, 215, 377.

15. Nason, A., and Lehman, I. R., Tocopherol as an activator of cytochrome $\mathrm{C}$ reductase. Science, 1955, 122, 19.

16. Martius, C., Thyroxin und oxydative Phosphorylierung. International Congress of Biochemistry, 3rd, Brussels, 1955. Proceedings. New York, Academic Press, 1956, p. 1.

17. Drill, V. A., Interrelations between thyroid function and vitamin metabolism. Physiol. Rev., 1943, 23, 355.

18. Rosenman, R. H., Friedman, M., and Byers, S. O., Observations concerning the metabolism of cho- lesterol in the hypo- and hyperthyroid rat. Circulation, $1952,5,589$.

19. Krane, S. M., Brownell, G. L., Stanbury, J. B., and Corrigan, H., The effect of thyroid disease on calcium metabolism in man. J. Clin. Invest., 1956, 35, 874.

20. Wheeler, R. S., and Perkinson, J. D., Jr., Influence of induced hypo- and hyperthyroidism on vitamin $\mathrm{E}$ requirement of chicks. Am. J. Physiol., 1949, 159, 287.

21. Butturini, U., Mechanism of action of vitamin $E$. Ateneo parmense, 1943, 15, 5.

22. Chrétien, H., Experimentelle Untersuchungen an Mensch und Tier über Kreatinurien und ihre Beeinflussbarkeit durch Dijodtyrosin und Vitamin $\mathrm{E}$. Ann. pædiat., 1944, 163, 225.

23. Quaife, M. L., and Harris, P. L., The chemical estimation of tocopherols in blood plasma. J. Biol. Chem., 1944, 156, 499.

24. Quaife, M. L., and Biehler, R., A simplified hydrogenation technique for the determination of blood plasma tocopherols. J. Biol. Chem., 1945, 159, 663.

25. Barker, S. B., Determination of protein-bound iodine. J. Biol. Chem., 1948, 173, 715.

26. Bloor, W. R., and Knudson, A., The separate determination of cholesterol and cholesterol esters in small amounts of blood. J. Biol. Chem., 1916, 27, 107.

27. Bruger, M., and Somach, I., The diurnal variations of the cholesterol content of the blood. J. Biol. Chem., 1932, 97, 23.

28. Turner, K. B., and Steiner, A., A long term study of the variation of serum cholesterol in man. J. Clin. Invest., 1939, 18, 45.

29. Keys, A., Anderson, J. T., and Mickelson, O., Serum cholesterol in men in basal and nonbasal states. Science, 1956, 123, 29.

30. Overman, R. S., McNeely, J. M., Todd, M. E., and Wright, I. S., Effects of vitamin E preparations on plasma tocopherol levels. J. Clin. Nutrition, 1954, 2, 168.

31. Statistical Bulletin, Metropolitan Life Insurance Company, 1942, 23, No. 10 , p. 8.

32. Statistical Bulletin, Metropolitan Life Insurance Company, 1943, 24, No. 6, p. 7.

33. Hillman, R. W., Nerb, L., and Hertz, H., The blood plasma vitamin $\mathrm{A} /$ carotene ratio and tocopherol concentration in relation to the metabolic state. Am. J. Digest. Dis., 1955, 22, 128.

34. Filer, L. J., Jr., Wright, S. W., Manning, M. P., and Mason, K. E., Absorption of $\alpha$-tocopherol and tocopherol esters by premature and full term infants and children in health and disease. Pediatrics, 1951, 8, 328.

35. Darby, W. J., Cherrington, M. E., and Ruffin, J. M., Plasma tocopherol levels in sprue. Proc. Soc. Exper. Biol. \& Med., 1946, 63, 310.

36. Harris, P. L., Hickman, K. C. D., Jensen, J. L., and Spies, T. D., Survey of the blood plasma levels 
of vitamin A, carotene, ascorbic acid, and tocopherols of persons in an area of endemic malnutrition. Am. J. Pub. Health, 1946, 36, 155.

37. Lemley, J. M., Gale, R. G., Furman, R. H., Cherrington, M. E., Darby, W. J., and Meneely, G. R., Plasma tocopherol levels in cardiac patients. Am. Heart J., 1949, 37, 1029.

38. Pomeranze, J., and Lucarello, R. J., Tocopherol response curves and fat absorption. J. Lab. \& Clin. Med., 1953, 42, 700.

39. Ferguson, M. E., Bridgforth, E., Quaife, M. L., Martin, M. P., Cannon, R. O., McGanity, W. J., Newbill, J., and Darby, W. J., The Vanderbilt cooperative study of maternal and infant nutrition. VII. Tocopherol in relation to pregnancy. J. Nutrition, 1955, 55, 305.

40. Klatskin, G., and Krehl, W. A., The significance of the plasma tocopherol concentration and of tocopherol tolerance tests in liver disease. J. Clin. Invest., 1950, 29, 1528.

41. Darby, W. J., Ferguson, M. E., Furman, R. H., Lemley, J. M., Ball, C. T., and Meneely, G. R., Plasma tocopherols in health and disease. Ann. New York Acad. Sc., 1949, 52, 328.

42. Trowell, H. C., Moore, T., and Sharman, I. M., Vitamin $E$ and carotenoids in the blood plasma in kwashiorkor. Ann. New York Acad. Sc., 1954, 57, 734.

43. Popper, H., Dubin, A., Steigmann, F., and Hesser,
F. P., Plasma tocopherol levels in various pathologic conditions. J. Lab. \& Clin. Med., 1949, 34, 648.

44. Hurxthal, L. M., Blood cholesterol and thyroid disease; III. Myxedema and hypercholesterolemia. Arch. Int. Med., 1934, 53, 762.

45. Boyd, E. M., and Connell, W. F., Thyroid disease and blood lipids. Quart. J. Med., n.s. 1936, 5, 455.

46. Peters, J. P., and Man, E. B., The interrelations of serum lipids in patients with thyroid disease. $\mathrm{J}$. Clin. Invest., 1943, 22, 715.

47. Bensley, E. H., Fowler, A. F., Creaghan, M. V., Moore, B. A., and McDonald, E. K., Plasma tocopherol in diabetes mellitus. J. Nutrition, 1950, 40, 323.

48. Weiss, S. B., and Marx, W., The fate of radioactive cholesterol in mice with modified thyroid activities. J. Biol. Chem., 1955, 213, 349.

49. Engel, $C$., Vitamin $E$ in human nutrition. Ann. New York Acad. Sc., 1949, 52, 292.

50. Simon, E. J., Eisengart, A., and Milhorat, A. T., A metabolite of vitamin $\mathrm{E}$ from human urine. Federation Proc., 1955, 14, 281.

51. Heinsen, H. A., Therapeutische Versuche mit Vitamin $\mathrm{E}$ bei Thyreotoxikosen, ein Beitrag zur Werkungsweise des Vitamins E. Med. Klin., 1947, 42, 823.

52. Williams, R. H., Antithyroid drugs. III. Comparison of results of newer forms of treatment of thyrotoxicosis. Arch. Int. Med., 1947, 80, 11. 